メチルセルロース水溶液の最点におよぼすスチレンスルホン酸ナトリウム 単量体とその重合体添加による塩溶と塩析効果

西田 幸次 ${ }^{* 1, *} \cdot$ 平林 哲雄 ${ }^{* 1} \cdot$ 田中健太郎 ${ }^{* 1} \cdot$ 森田 秀幸*1 松葉 豪*2 金谷 利治*1

\title{
Salting-In and Salting-Out Effects on Cloud Point of Aqueous Methylcellulose by Addition of Monomeric and Polymeric Sodium Styrene Sulfonate
} \author{
Koji Nishida $^{* 1, \#}$, Tetsuo Hirabayashi
and Toshiji Kanaya
a1 \\ ${ }^{* 1}$ Institute for Chemical Research, Kyoto University, Uji, Kyoto-fu 611-0011, Japan \\ E-mail : knishida@scl.kyoto-u.ac.jp \\ ${ }^{* 2}$ Department of Polymer Science and Engineering, Faculty of Engineering, Yamagata University, \\ 4-3-16 Jonan, Yonezawa, Yamagata 992-8510, Japan
}

\begin{abstract}
Methylcellulose attains the water-solubility by reducing the strong hydrogen-bonding. The reduction of the hydrogen bonding is achieved by partially substituting hydrophobic methoxy group for hydroxy group in cellulose. However, the substitution gives double-bladed property to the aqueous methylcellulose, namely, excessive substitution makes again methylcellulose insoluble in water. Therefore, the water-solubility of methylcellulose is strongly affected by the degree of substitution and moreover the distribution of the substituents. In this study, however, for a commercially available methylcellulose we have modified the cloud point by the addition of various organic salts. Sodium styrene sulfonate (NaSS) showed a strong salting-in effect, whereas the polymeric NaSS, i.e., sodium polystyrene sulfonate (NaPSS), showed oppositely a salting-out effect.
\end{abstract}

(Received 6 June, 2015 ; Accepted 30 July, 2015)

\section{1. 緒 言}

セルロース誘導体の一つであるメチルセルロースは, セルロース中の水酸基 $(-\mathrm{OH})$ の一部をメトキシ基 $\left(-\mathrm{OCH}_{3}\right)$ に置換することにより強い凝集作用を持つ水酸 基間の水素結合を弱め, 水に可溶化させたものである. メチルセルロース水溶液の特徽の一つは, 室温では透明 な液体であるが数十 ${ }^{\circ} \mathrm{C} に$ 加熱することで相分離を起こす， いわゆる下部臨界完溶型 (LCST 型) の挙動を示すことであ る。適度なメトキシ基の導入によりセルロースは水に可 溶化するが, 過度のメトキシ基の導入は踈水性を増大さ せ可溶化を損なう方向にも働く。したがって, メトキシ 基の導入率の大小がメチルセルロースの水溶性に大きく 影響する. さらに, 平均值としてのメトキシ基の導入率 だけでなくグルコピラノース環当り 3 ヶ所ある水酸基の 3 ケ所とも置換されたユニットのブロック性が水溶性やゲ ル化に大きく関与することが明らかとなってきている

\# corresponding author

*1 京都大学化学研究所

*2 山形大学工学部
[1-4]. 実験室レベルでの精密構造制御の発展 [5]の一方で, 工業的に大量生産されるメチルセルロースは既に産業界 の様々な分野で利用されており $[6]$, 今後もさらなる用途 開発が期待されている. 本研究では, 工業的に得られた 既定の平均のメトキシ基の導入率と分子量を持つメチル セルロースの水溶液に対して種々の有機塩を添加するこ とで量点を変化させることを試みた．

水に溶解や分散しているタンパク質やコロイドに塩類 を添加することで沈殿や凝集を起こす現象は, 塩析とし て知られている. 逆に, 可溶化が促進する場合は, 塩溶 と呼ばれる，塩析や塩溶を起こす条件は，溶質および添 加する塩の種類や濃度はもとより温度にも依存する。

LCST 型の挙動を示すメチルセルロース水溶液の場合, 均一な一相状態となる温度域が転移点の低温側に位置す るため, 塩類の添加により転移温度が低下すれば塩析で あり，逆に，上昇すれば塩溶となる。

たんぱく質やコロイドに対する各種のカチオンとアニ オンによる塩析効果の大小は, ホフマイスター系列とし て知られている $[7,8]$. 代表的なカチオンに関してその一 部を示すと, $\mathrm{Li}^{+}>\mathrm{Na}^{+}>\mathrm{K}^{+}>\mathrm{Cs}^{+}$. アニオンでは, $\mathrm{SO}_{4}{ }^{2-}>$ $\mathrm{Cl}^{-}>\mathrm{NO}^{3-}>\mathrm{I}^{-}$のごとくとなる. 左にいくほど塩析的に働 
き, 右にいくほど塩溶的に働く. メチルセルロースの水 溶液に対しても塩化ナトリウム $(\mathrm{NaCl})$ やヨウ化ナトリウ ム $(\mathrm{NaI})$ などの無機塩を添加することで塩析や塩溶効果を 示すことが既に報告されている $[9,10]$.

本研究では, 以下に述べる三種類の有機塩を選定し, これらを添加した際のメチルセルロース水溶液の LCST 型の挙動に与える効果を調べることとした.

まず始めに, 塩類としてはやや馴染みが薄いが, スチ レンスルホン酸ナトリウム $\left(\mathrm{C}_{8} \mathrm{H}_{7} \mathrm{SO}_{3} \mathrm{Na}\right.$, 以下 $\mathrm{NaSS}$ と略 す)を有機塩として選定した，その意図としては，強酸型 の解離基を有しながら有機の疎水部を合わせ持つため, メチルセルロース側の疎水部との何らかの相互作用を期 待してのことである. 次に, ポリスチレンスルホン酸ナ トリウム $\left(\left[-\mathrm{C}_{8} \mathrm{H}_{7} \mathrm{SO}_{3} \mathrm{Na}-\right]_{\mathrm{n}}\right.$, 以下 $\mathrm{NaPSS}$ と略す $)$ を選定し た. NaPSS は, NaSS の重合体であり代表的な合成高分子

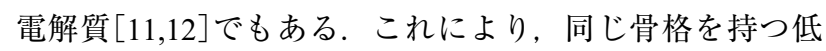
分子の有機塩と高分子の有機塩 (高分子電解質) との効果 を比較することができる. 最後にアニオン性高分子電解 質とカチオン性高分子電解質との比較を目的として, キ トサン塩酸塩を高分子有機塩として選定した. キトサン 塩酸塩も高分子電解質であるが $[13,14]$, NaPSS が解離に よりポリアニオンとなり低分子カチオンである $\mathrm{Na}^{+}$を放出 するのに対してキトサン塩酸塩はポリカチオンとなり低 分子アニオンである $\mathrm{Cl}^{-}$を放出する点が異なる.

\section{2. 実 験}

\section{1 試 料}

メチルセルロース試料には, 信越化学工業株式会社か ら提供されたメトローズ SM-4 を用いた. グルコピラノー ス環当り 3 ヶ所ある水酸基に対して, メトキシ基で置換 された平均の割合 $(D S)$ および重量平均分子量 $\left(M_{\mathrm{w}}\right)$ はそれ ぞれ約 1.77 および約 $2.5 \times 10^{4}$ である. 緒言で述べた添加 塩として, 以下の市販品を用いた， $\mathrm{NaSS}$ (東京化成), $\operatorname{NaPSS}\left(M_{\mathrm{w}}=\right.$ 約 $7 \times 10^{4}$, Aldrich) およびキトサン塩酸塩 (PROTASAN UP CL 113, NovaMatrix).

メチルセルロース試料は熱水法で均一に溶解させた後, 各種の添加塩を加えて所定の濃度の試料溶液とした。

\section{2 測 定}

試料溶液の量点を決めるための透過光強度測定は, 波 長 $405 \mathrm{~nm}$ のダイオードレーザーを光源とする自作の装置 により行った.この透過光強度測定装置は, 既報の高分 解能小角光散乱装置[15] と共通の光学系を用いることで 散乱光の混入を抑えて透過光をモニターすることができ るようにデザインされている. 各試料溶液の透過光強度 の值は，透明状態での值で除した百分率で示した.

試料溶液は, 厚さ約 $0.15 \mathrm{~mm}$ の 2 枚のカバーで厚さ約 $0.5 \mathrm{~mm}$ のスペーサーを挿んで封入し, 測定に用いた.

試料溶液の温度調節には Mettler 社 FP82HT を用い, 昇 温速度 $3{ }^{\circ} \mathrm{C} / \mathrm{min}$ で透過光強度測定を行った。

\section{3. 結果と考察}

\section{1 量 点}

セルロース誘導体の水溶液の昇温過程での透過光強度 の低下の仕方は, 用いた試料の素性により様々な様相を 呈する. 昇温過程中のある狭い温度範囲内で急激に透過 光強度が低下するものもあれば, 広い温度範囲にわたっ て緩慢に低下するものもある，その理由としては， $M_{\mathrm{w}} や$ その分布の違い, また, 緒言で述べたように $D S$ やその 分布の違い[1-5]が深く関わっていると考えられるが, ゲ ル化と相分離が競合して起こるため[16-18], 実験により 平衡状態の精確な相図を決めることが本質的に困難な系 でもある. 本研究で用いた試料の場合, やや特殊な透過 光強度の低下の仕方を示したので, 以下でそれに見合っ た曇点の評価法を提案する.
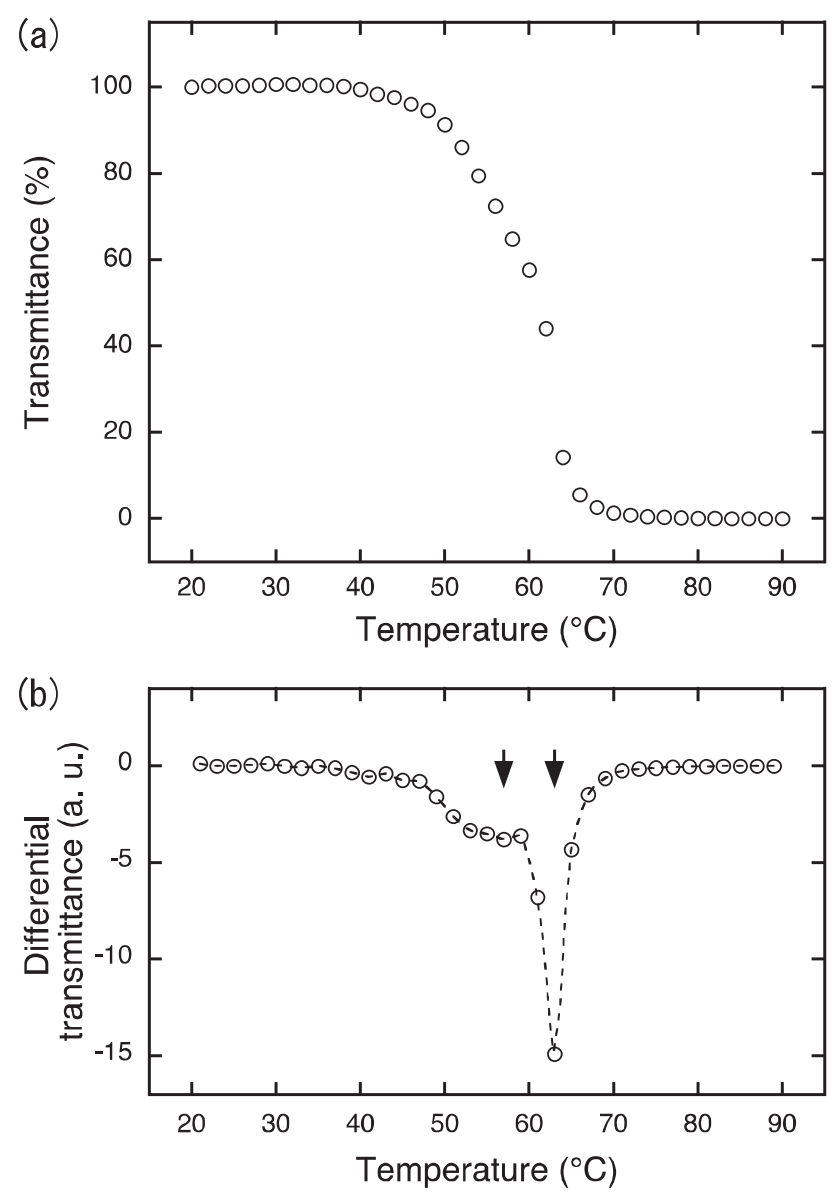

Fig. 1 a : Light transmittance curve as a function of temperature for aqueous methylcellulose (SM-4, $8 \mathrm{wt} \%$ ). b : Differential light transmittance curve as a function of temperature for the upper figure.

図 1a は, 濃度 $8 \mathrm{wt} \%$ の試料溶液（塩は無添加）に対する 昇温過程での透過光強度の測定例である. $40^{\circ} \mathrm{C}$ 付近で透 過光強度が低下し始めている. 一方, $63^{\circ} \mathrm{C}$ 付近で透過光 強度が急激に低下していることが判る. すなわち, 緩急 二段階で白濁が進行している．この特徴をより詳細に検 討するために, 透過光強度曲線を微分したのが図 $1 b$ であ る. 図中 2 つの下向き矢印で示したように低温側に幅広 
の極小 (もしくはショルダー) と高温側にシャープな極小 が存在する. これらの 2 つの特徵的な温度は, 本研究と 類似の条件で測定された示差走查熱量測定 (DSC)で観測 された 2 つ吸熱ピーク [4]のものと概ね一致する. メチ ルセルロース水溶液の昇温過程の DSC で観察される吸熱 ピークは, 脱水和によるものとされている [19]. 脱水和 は既に室温付近から徐々に始まる [9]. 凝集や架橋点の形 成は部分的な脱水和でも可能なため比較的低温でも起る のに対して, 相分離は分子全体にわたる広範な脱水和を 伴うため比較的高温側で起こることなる.したがって, 低温側の緩慢な透過光強度の低下はゲル化もしくはその 前駆段階の凝集 (プレゲル)構造形成 [17]によって光を散 乱したためであり, 高温側の急激な透過光強度の低下が 相分離によるものと考えるのが妥当であろう.よって, 後者を本研究における量点とすることとした。一方, ゲ ル化や凝集の影響を受け難い試料の場合は, 透過光強度 の低下は狭い温度範囲内で急激に起こるものと考えられ る.

\section{2 量点のメチルセルロース濃度依存性}

図 $2 \mathrm{a}$ は, メチルセルロースの濃度を $2 \mathrm{wt} \%$ から $10 \mathrm{wt} \%$ まで変化させて透過光強度曲線を調べたものである．前 節で述べた微分法により求めた量点のメチルセルロース 濃度依存性を図 $2 b$ に示す．濃度が高くなるにつれて量点 は低下したが, 測定した濃度範囲における温度の低下の 幅は高々 $6{ }^{\circ} \mathrm{C}$ 程度であり, 高濃度になるほど $(z 6 \mathrm{wt} \%)$ そ の依存性は弱くなった.この傾向は, 他の実験報告 [9]や 理論的予測 $[16]$ とも一致する.
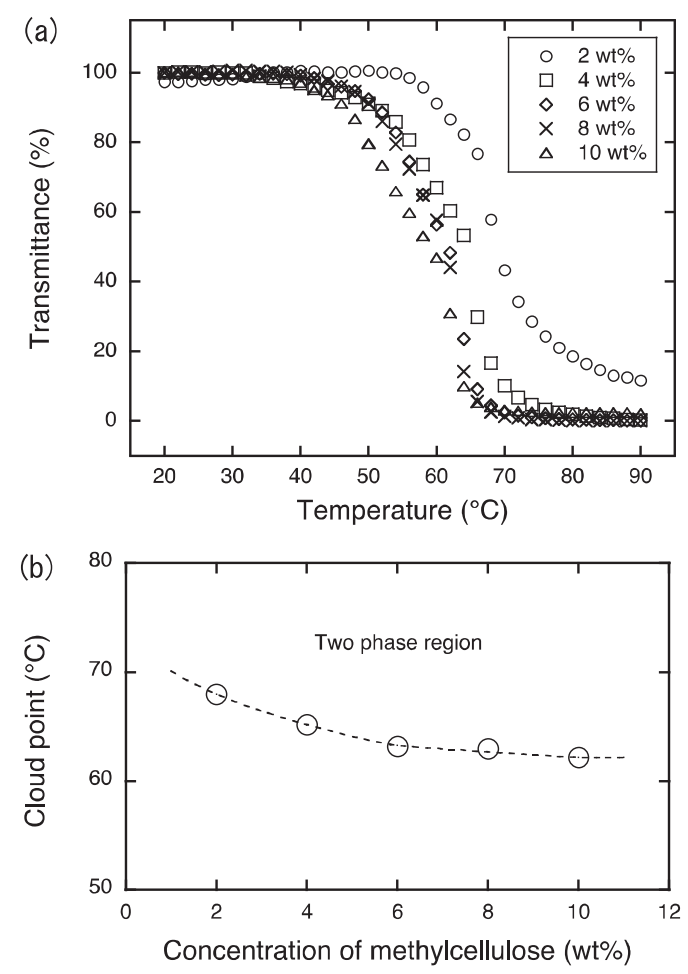

Fig. 2 a : Light transmittance curves as a function of temperature for various concentrations of aqueous methylcellulose (SM-4). b : Cloud point as a function of methylcellulose concentration.
なお, 別のパラメーターを走査する際の濃度条件が同 じ試料溶液を再度調製して測定している(例えば図 $2 \mathrm{a}$ の $6 \mathrm{wt} \%$ と図 3 の NaSS 濃度 0$)$. 試料溶液の調製過程等で生 じたと思われる実験誤差により透過光強度曲線自体には 微妙な差が見られるが, 微分法により求めた曇点として 見た場合の誤差は $1{ }^{\circ} \mathrm{C}$ 程度であった。 したがって, 図 $2 b$ における誤差はデー夕点の記号の大きさ程度である。

\section{3 量点に与える各種有機塩の効果}

図 3 はメチルセルロース水溶液に有機塩の NaSS を添加 した際の透過光強度曲線を調べたものである．塩類の濃 度は電解質を扱う際の慣例により $\mathrm{mol} / \mathrm{L}(\mathrm{M})$ を単位として 用いた (高分子電解質の場合は, モノマー単位での濃度). 添加塩濃度の増加に伴い量点が大きく高温側にシフトし， NaSS がメチルセルロース水溶液に対して非常に強い塩溶 効果を示すことが判明した.この結果に関する考察は, NaPSS やキトサン塩酸塩を添加した際の結果と合わせて 行うこととする.

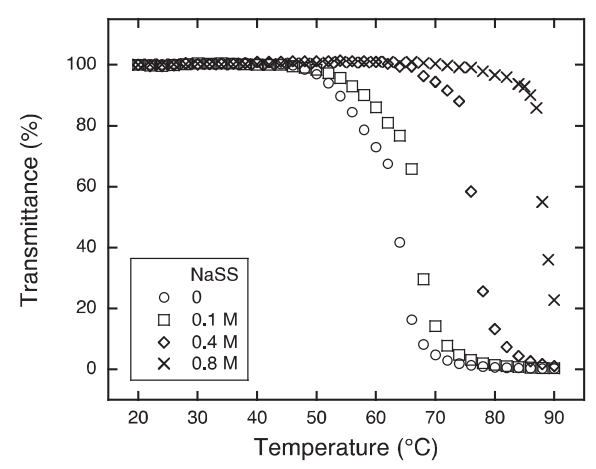

Fig. 3 Light transmittance curves as a function of temperature for aqueous methylcellulose (SM-4, $6 \mathrm{wt} \%$ ) with various NaSS concentrations.

図 4 はメチルセルロース水溶液に高分子有機塩の NaPSS を添加した際の透過光強度曲線を調べたものであ る. 今度は NaSS を添加した場合とは逆に, 塩濃度の増加 に伴い量点が低温側にシフトし, NaPSS がメチルセルロー ス水溶液に対して一般的な塩析効果を示すことがわかる. 重合体であるか否かにより塩析と塩溶の効果が反転する という興味深い現象である。

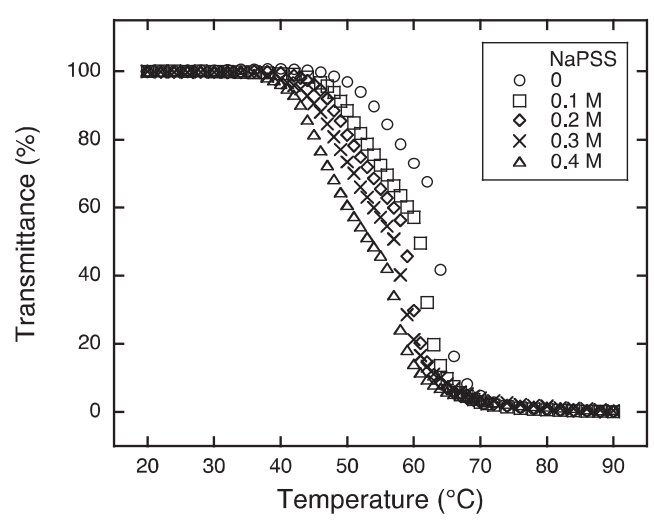

Fig. 4 Light transmittance curves as a function of temperature for aqueous methylcellulose (SM-4, $6 \mathrm{wt} \%$ ) with various NaPSS concentrations. 
図 5 はメチルセルロース水溶液に高分子有機塩のキト サン塩酸塩を添加した際の透過光強度曲線を調べたもの である．透過光強度の低下し始めの挙動が NaPSS を添加 した場合に比べて若干緩やかであること以外はNaPSS の 場合とほぼ一致している。すなわち, カチオン性高分子 電解質であるキトサン塩酸塩とアニオン性高分子電解質 であるNaPSS とが共に類似の塩析効果を示したことにな る.

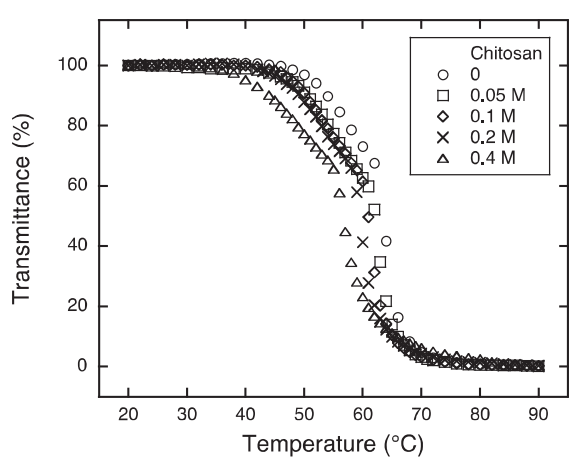

Fig. 5 Light transmittance curves as a function of temperature for aqueous methylcellulose (SM-4, $6 \mathrm{wt} \%$ ) with various Chitosan concentrations.

図 6 は透過光強度曲線に微分法を適用して得られた曇 点を添加塩濃度に対してプロットしたものである. NaSS を添加した場合は量点が大きく上昇し，NaPSS やキトサ ン塩酸塩を添加した場合は量点が低下する様子が明瞭に 読み取れる. 図 4 と図 5 の挙動が類似していたことから 推察されたように, NaPSS とキトサン塩酸塩のプロット がほぼ重なっており, 定量的にも同等の塩析効果を示し たことになる。いずれの場合も添加塩濃度に対して曇点 はおよそ一次関数的な変化を示しているが, 高濃度側で 変化が鈍化する傾向もみられるため, 初期勾配から添加 塩の単位濃度当りの曇点の変化量を見積もることにした その結果は, 図中の三角形の勾配で示すように, NaPSS とキトサン塩酸塩では $-19^{\circ} \mathrm{C} / \mathrm{M}$ の塩析効果であり, $\mathrm{NaSS}$ では+ $33^{\circ} \mathrm{C} / \mathrm{M}$ の塩溶効果であった.

メチルセルロース水溶液に典型的な無機塩である $\mathrm{NaCl}$ および NaI を添加した場合の量点に対する添加塩濃度依

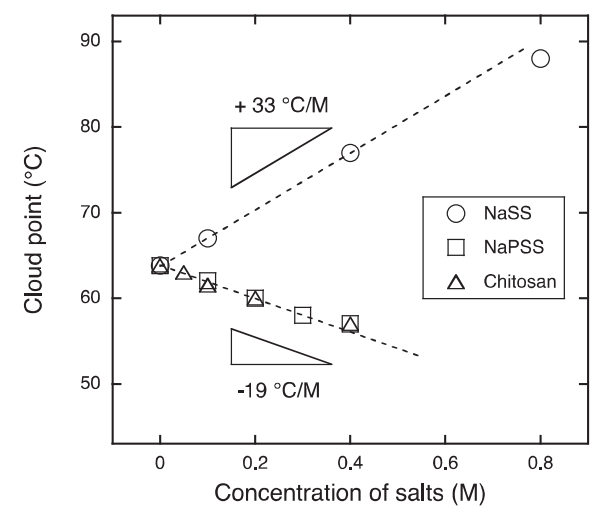

Fig. 6 Cloud point as a function of concentration of added salts.
存性を既報の文献[10]の表 1 に与えられた值を基に初期 勾配から抽出すると, それぞれ, $-34.5^{\circ} \mathrm{C} / \mathrm{M}(\mathrm{NaCl})$ の塩 析効果および $+11^{\circ} \mathrm{C} / \mathrm{M}(\mathrm{NaI})$ の塩溶効果であった. NaPSS やキトサン塩酸塩を添加した際の $-19^{\circ} \mathrm{C} / \mathrm{M}$ という值は, 文献から抽出した $\mathrm{NaCl}$ の $-34.5^{\circ} \mathrm{C} / \mathrm{M}$ に比べておよそ半分 という比較的小さな塩析効果であると言える. 一方, NaSS を添加した際の $+33^{\circ} \mathrm{C} / \mathrm{M}$ という值は, 典型的な塩溶効果 を示す無機塩である $\mathrm{NaI}$ の $+11^{\circ} \mathrm{C} / \mathrm{M}$ に比べて実に 3 倍も の塩溶効果を示したことになる．以下でこれらの值の意 味するところを考察する.

電解質溶液の溶媒の質を議論する際に, イオン強度 $I$ が用いられる. 電荷数 $z_{+}$のカチオンと電荷数 $z_{-}$のアニオ ンとからなる濃度 $C_{\mathrm{s}}$ の低分子塩のイオン強度 $I$ は, 次式 で与えられ，イオンの正負の符号に関係なく共にイオン 強度としてカウントされる。

$$
I=(1 / 2)\left(z_{+}{ }^{2}+z_{-}{ }^{2}\right) C_{\mathrm{s}}
$$

一方, 高分子電解質の場合, 解離した対イオン (NaPSS の 場合は $\left.\mathrm{Na}^{+}\right)$はイオン強度としてカウントされるが, ポリ イオン側の重合度の個数分ある解離基 $\left(-\mathrm{SO}_{3}{ }^{-}\right)$は高分子鎖 上に固定されているため溶媒中を自由に動くことができ ず, 通常, 溶媒のイオン強度としてはカウントされない [12,20,21]. あるいは, ポリイオンのように巨大であって も数密度の低い種は, 束一的性質への寄与が非常に小さ いという解釈にもなる. したがって, この時点で, 高分 子塩が静電的な効果として溶媒の質に関与できる割合は 低分子塩の半分ということになり, メチルセルロース水 溶液に対する NaPSS の塩析効果の弱さが説明できる. 一 方, 高分子電解質の対イオン凝集理論 $[22,23]$ によと, 全対イオンの内の一定の割合(NaPSS のような骨格がビニ ル型の場合, 約 2/3)がポリイオン近傍に分布し, 逆に, ポリイオンから離れた領域における分布は低くなるとさ れている.このような対イオン分布の偏りにより, 塩析 効果にも空間的に偏りが生じている可能性も考えられる. しかし，量点を通して見た今回の実験条件では, 対イオ ン分布の偏りは，影響していないようである.

図 6 で示したように, NaPSS とキトサン塩酸塩の塩析 効果がほぼ同等であった。 ここで, NaPSS やキトサン塩 酸塩の解離後のポリイオン側が塩析や塩溶効果に全く関 与しないと仮定するならば, NaPSS とキトサン塩酸塩の 塩析効果の同等性は, それらの対イオンであるカチオン $\left(\mathrm{Na}^{+}\right)$とアニオン $\left(\mathrm{Cl}^{-}\right)$の効果の同等性に帰することができ る. 高分子塩を用いることは, 対イオン独自の塩析や塩 溶効果の大小を評価する一つの指針となろう.

最後に, NaSS がメチルセルロース水溶液に対して非常 に強い塩溶効果を示すことの考察を行う. 低分子の無機 塩による塩析効果は, 塩が解離して生じたイオンが水和 することで溶媒である水が構造を形成し，たんぱく質な どの溶質に対する溶媒としての効力が低下するためと定 
性的に説明される. 塩溶効果は, 逆に, 水の構造形成を 阻害することで生じるとされる. 古くは，この考え方は バルク状態での溶媒(水)に対して当てはまると考えられ てきたが, 溶質と溶媒との界面近傍へのイオンの吸着や 枯渇といった局所的な挙動が主要因との見方に移ってき た $[8,24]$. 一般に, 電子を失ったカチオンの方が電子を得 たアニオンに比べてイオン半径が小さい. イオン半径が 小さなカチオンは水和され易く, 逆に, $\mathrm{I}^{-}$等のイオン半径 が大きなアニオンは水和され難く, 溶質界面へ吸着する 傾向を持つ. イオンが吸着すれば溶質が見掛上電荷を持 つことになり溶解し易くなる(塩溶効果)とされる $[8]$.

NaSS は低分子とはいえ, ベンゼン環に結合したビニル基 という比較的大きな疎水性部位を有する。しがたって, $\mathrm{SS}^{-}$ は $\mathrm{I}^{-} よ り も さ ら に$ 水和され難く, 溶質界面へ吸着する傾 向も特に強いアニオンである. その結果, NaSS は, NaI よりも強い塩溶効果をもたらしたものと考えられる。

本研究で選定した塩類とその濃度により塩溶側へは既 報の塩類の効果をしのぎ $90^{\circ} \mathrm{C}$ 近傍まで曇点を拡張できた が, 塩析側へは既報の事例に対しての優位性は得られな かった. なお, 塩析側に関しては, クエン酸やポリエチ レングリコールを添加することでゲル化温度を大きく体 温付近まで下げることができる $[25]$.

最後に, 強い塩溶効果を持つ添加塩の用途に関してコ メントしておく，低置換度のセルロース誘導体が, 高機 能繊維材料として応用されている $[26,27]$. しかし, 置換 度の低過ぎや高過ぎのセルロース誘導体は難水溶性であ り工程中の加工性が問題となる。このような場合に強力 な塩溶化剂が効果を発揮するものと期待される.

\section{謝 辞}

本研究の一部は日本学術振興会科学研究費助成事業に より行った。

試料をご提供いただいた信越化学工業株式会社に謝意 を表します。また，終始有益なご助言を頂いた同社の谷 岡荘治様と早川和久様に御礼申し上げます.

\section{文 献}

1. T. Kato, M. Yokoyama, and A. Takahashi, Colloid Polym. Sci., 256, 15 (1978).

2. H. Kamitakahara, F. Nakatsubo, and D. Klemm, Cellulose, 13, 375 (2006).

3. K. Sakakibara, T. Takano, and F. Nakatsubo, Cellulose, 18, 105 (2011).
4. A. Nakagawa, D. Fenn, A. Koschella, T. Heinze, and H, Kamitakahara, J. Polym. Sci., B : Polym. Phys., 49, 1539 (2011).

5. H. Kamitakahara, Mokuzai Gakkaishi, 60, 144 (2014).

6. K. Hayakawa, Sen'i Gakkaishi (J. Soc. Fiber Sci. \& Technol., Jpn), 70, P-452 (2014).

7. F. Hofmeister, Arch. Exp. Pathol. Pharmakol., 24, 247 (1888).

8. P. Alexandridis, and J. F. Holzwarth, Langmuir, 13, 6074 (1997).

9. N. Sarkar, J. Appl. Polym. Sci., 24, 1073 (1979).

10. Y. Xu, and L. Li, Polymer, 46, 7410 (2005).

11. K. Nishida, K. Kaji, T. Kanaya, and T. Shibano, Macromolecules, 35, 4084 (2002).

12. K. Nishida, Sen'i Gakkaishi (J. Soc. Fiber Sci. \& Technol., Jpn), 61, P-14 (2005).

13. N. Boucard, L. David, C. Rochas, A. Montembault, C. Viton, and A. Domard, Biomacromolecules, 8, 1209 (2007).

14. K. Tanaka, K. Nishida, B. J. Gabrys, M. J. Lawrence, and T. Kanaya, Sen'i Gakkaishi (J. Soc. Fiber Sci. \& Technol., Jpn), 70, 225 (2014).

15. K. Nishida, H. Ogawa, G. Matsuba, T. Konishi, and T. Kanaya, J. Appl. Cryst., 41, 723 (2008).

16. F. Tanaka, and M. Ishida, J. Chem. Soc. Faraday Trans., 91, 2663 (1995).

17. K. Kobayashi, C. Huang, and T. Lodge, Macromolecules, 32, 7070 (1999).

18. H. Takeshita, K. Saito, M. Miya, K. Takenaka, and M. Shiomi, J. Polym. Sci., B : Polym. Phys., 48, 168 (2010).

19. N. Sarkar, and L. C. Walker, Carbohydrate Polymers, 27, 177 (1995).

20. K. Nishida, K. Kaji, and T. Kanaya, Polymer, 42, 8657 (2001).

21. K. Nishida, K. Kaji, and T. Kanaya, J. Chem. Phys., 115, 8217 (2001).

22. F. Oosawa, J. Polym. Sci., 23, 421 (1957).

23. G. S. Manning, J. Chem. Phys., 51, 924 (1969).

24. Y. Zhang, S. Furyk, D. E. Bergbreiter and P. S. Cremer, J. Am. Chem. Soc., 127, 14505 (2005).

25. M. Takeuchi, S. Kageyama, H. Suzuki, T. Wada, Y. Toyoda, T. Oguma, Y. Ezure, Y. Tsuriya, T. Kato, and F. Ishii, Material Technology, 17, 445 (1999).

26. K. Hayakawa, Cellulose Commun., 11, 26 (2004).

27. M. Kiyose, E. Yamamoto, C. Yamane, T. Midorikawa, and T. Takahashi, Polym. J., 39, 703 (2007). 